\title{
DNA repair protein DNA-PK protects PC12 cells from oxidative stress-induced apoptosis involving AKT phosphorylation
}

\author{
Alessio Cardinale ${ }^{1}$. Serena Saladini ${ }^{1}$. Leonardo Lupacchini ${ }^{1} \cdot$ Irene Ruspantini $^{2}$ - Chiara De Dominicis ${ }^{1,3}$. \\ Marco Papale $^{1} \cdot$ Francesca Silvagno $^{4} \cdot$ Enrico Garaci $^{5} \cdot$ Cristiana Mollinari $^{3,6} \cdot$ Daniela Merlo $^{3}$ ()
}

Received: 24 March 2021 / Accepted: 5 November 2021 / Published online: 19 November 2021

(c) The Author(s) 2021

\begin{abstract}
Background Emerging evidence suggest that DNA-PK complex plays a role in the cellular response to oxidative stress, in addition to its function of double strand break (DSB) repair. In this study we evaluated whether DNA-PK participates in oxidative stress response and whether this role is independent of its function in DNA repair.

Methods and results We used a model of $\mathrm{H}_{2} \mathrm{O}_{2}$-induced DNA damage in PC12 cells (rat pheochromocytoma), a well-known neuronal tumor cell line. We found that $\mathrm{H}_{2} \mathrm{O}_{2}$ treatment of PC12 cells induces an increase in DNA-PK protein complex levels, along with an elevation of DNA damage, measured both by the formation of $\gamma \mathrm{H} 2 \mathrm{AX}$ foci, detected by immunofluorescence, and $\gamma \mathrm{H} 2 \mathrm{AX}$ levels detected by western blot analysis. After $24 \mathrm{~h}$ of cell recovery, $\gamma \mathrm{H} 2 \mathrm{AX}$ foci are repaired both in the absence and presence of DNA-PK kinase inhibitor NU7026, while an increase of apoptotic cells is observed when DNA-PK activity is inhibited, as revealed by counting pycnotic nuclei and confirmed by FACS analysis. Our results suggest a role of DNA-PK as an anti-apoptotic factor in proliferating PC12 cells under oxidative stress conditions. The anti-apoptotic role of DNA-PK is associated with AKT phosphorylation in Ser473. On the contrary, in differentiated PC12 cells, were the main pathway to repair DSBs is DNA-PK-mediated, the inhibition of DNA-PK activity causes an accumulation of DNA damage.

Conclusions Taken together, our results show that DNA-PK can protect cells from oxidative stress induced-apoptosis independently from its function of DSB repair enzyme.
\end{abstract}

Daniela Merlo

daniela.merlo@iss.it

Alessio Cardinale

cardinal@uniroma2.it

Serena Saladini

serena.saladini@live.it

Leonardo Lupacchini

leonardo.lupacchini@sanraffaele.it

Irene Ruspantini

irene.ruspantini@iss.it

Chiara De Dominicis

chiaradedominicisjob@gmail.com

Marco Papale

marcopapale@hotmail.it

Francesca Silvagno

francesca.silvagno@unito.it

Enrico Garaci

garenco@icloud.com
Cristiana Mollinari

cristiana.mollinari@ift.cnr.it

1 Molecular and Cellular Neurobiology, IRCCS San Raffaele Roma, Via di Val Cannuta 247, 00166 Rome, Italy

2 FAST. Istituto Superiore di Sanita', Viale Regina Elena 299, 00161 Rome, Italy

3 Department of Neuroscience, Istituto Superiore di Sanita, Viale Regina Elena 299, 00161 Rome, Italy

4 Department of Oncology, University Torino, via Santena 5 bis, 10126 Torino, Italy

5 University San Raffaele, Via di Val Cannuta 247, 00166 Rome, Italy

6 Institute of Translational Pharmacology, National Research Council, Via Fosso del Cavaliere 100, 00133 Rome, Italy 


\section{Graphical Abstract}
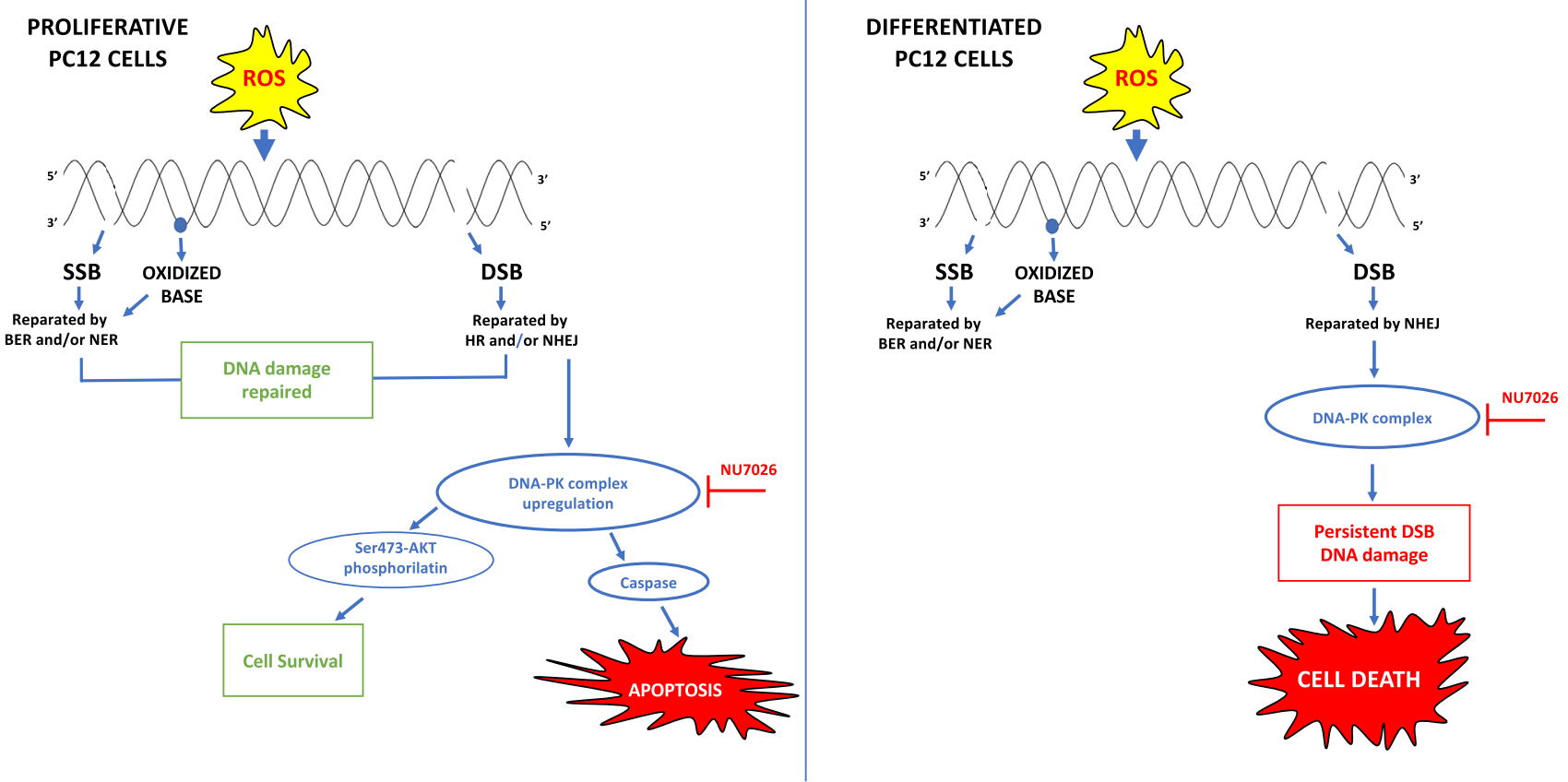

Keywords DNA-PK $\cdot$ DNA damage $\cdot$ DNA repair $\cdot$ Oxidative stress $\cdot$ Apoptosis

\section{Introduction}

Oxidative stress induces DNA damage, and the unrepaired or improperly repaired DNA lesions increase genomic instability, which can cause cell death, senescence, or dysregulation of cellular functions. Oxidative stress can induce cellular damage by Reactive Oxygen Species (ROS) generation, which are constantly produced inside the cell and able to cause modifications or alterations of DNA with serious consequences especially for neuronal cells that last throughout life [1-3]. DNA damages induce and coordinate a complex signal-transduction network composed by several pathway activation, collectively named DNA Damage Response (DDR), which can detect DNA lesions and arrest the cell cycle or promote cell death (apoptosis) in case of severe and irreparable damage [4-6]. In mammalian cells, the most severe form of DNA damage (double strand breaks, DSBs) is repaired by non-homologous end joining (NHEJ) and homologous recombination (HR) [7, 8]. NHEJ is considered the prevalent DSB repair pathway operating in neurons, which relies on the DNA-dependent protein kinase (DNAPK) complex [9].

DNA-PK is a PI3 kinase family member (which includes also Ataxia telangiectasia and Rad3-related, ATR and Ataxia-telangiectasia mutated kinase, ATM) preferentially phosphorylating serine and threonine residues followed by a glutamine, although other S-T/hydrophobic residues are also phosphorylated [10-12]. The active protein is a trimeric complex composed of the catalytic subunit, DNAdependent protein kinase catalytic subunit (DNA-PKcs), and the Ku70/86 heterodimer which binds to DNA ends with very high affinity and functions as regulatory subunit that stimulates DNA-PKcs kinase activity [13]. Moreover, the $\mathrm{Ku}$ subunits have been implicated in the cellular response to oxidative stress [14]. In addition to its role in DNA DSB repair, DNA-PK has been involved in several pathways including stress response modulation, apoptosis, telomere homeostasis and specific gene transcription [15]. The other members of PI3 kinase family, such as ATM, also has been involved in oxidative stress response and can be directly activated by hydrogen peroxide $\left(\mathrm{H}_{2} \mathrm{O}_{2}\right)[16,17]$. Indeed ROS over-production leads to rapid ATM dimerization/activation and downstream ATM signalling thus modulating cellular metabolism and cell survival, repairing oxidative DNA damage, and inducing antioxidant enzyme expression to maintain redox homeostasis $[16,18]$. ROS can also activate DNA-PK and its downstream signalling similar to ATM [19]. Indeed, DNA-PK has been found to associate with base excision repair (BER) protein complex essential for removing oxidative base damage [20]. Among the BER components, X-ray repair cross-complementing protein 1 (XRCC1) directly interacts with and is phosphorylated by DNA-PK [21]. In 
addition, Peddi et al. reported that DNA-PKcs deficiency compromises BER activity and inhibits the efficient processing of DNA lesions induced upon IR or $\mathrm{H}_{2} \mathrm{O}_{2}$ treatment [22]. Although recent evidences have implicated a role of DNA-PK in oxidative stress response [19], the molecular mechanism by which DNA-PK functions in the oxidative stress response remains to be elucidated.

In this study we evaluated whether DNA-PK participates in oxidative stress response and whether this role is independent of its function of DNA repair. To test this hypothesis, we used a $\mathrm{H}_{2} \mathrm{O}_{2}$-mediated oxidative stress model in rat pheochromocytoma line 12 (PC12) cells, a well-known neuronal cell line, to study the effect of oxidative stress on DNA-PK complex expression levels and function.

Our data clearly demonstrate that the DNA-PK complex expression and activity are stimulated by oxidative stress. Enhanced apoptosis in the presence of DNA-PK kinase inhibitor provides evidence that its role of reparative DNA enzyme is disjuncted by its antiapoptotic role. Indeed, we found that accumulated Histone H2AX phosphorylation $(\gamma \mathrm{H} 2 \mathrm{AX})$ foci are repaired after $24 \mathrm{~h}$ recovery both in the absence and presence of DNA-PK inhibitor.

In conclusion, our study indicates that DNA-PK may have a crucial role in cellular oxidative stress response and the enhancement of its activity may open new perspectives for the treatment of ROS-related diseases.

\section{Materials and methods}

\section{Cell culture and treatments}

PC12 cells were a kind gift from Prof. Silvia Biocca, Università degli Studi di Roma Tor Vergata, Dipartimento di Medicina dei Sistemi (original source: LA Green's lab [23].

PC12 cells were cultured and passaged as previously described [24]. Briefly, PC12 cells were cultured in RPMI 1640 medium (invitrogen) supplemented with $10 \%$ horse serum (HS, Euroclone), 5\% fetal bovine serum (Euroclone), $2 \mathrm{mM}$ L-glutamine (BioWest), 100 units/ml penicillin and $100 \mu \mathrm{g} / \mathrm{ml}$ streptomycin (BioWest). The cells were cultured on $100-\mathrm{mm} / 35 \mathrm{~mm}$-diameter tissue culture dishes (Falcon ${ }^{\mathrm{TM}}$, BD Biosciences) and maintained in a $37^{\circ} \mathrm{C}$ incubator in a water-saturated, $5 \% \mathrm{CO} 2$ atmosphere. When the cultured cells reached $80-90 \%$ confluency (split ratio 1:4), they were detached by trypsinization ( $0.025 \%$ trypsin-EDTA) and subcultured. Cells were centrifuged and harvested after trypsinization (0.025\% trypsin-EDTA).

To induce neuronal differentiation, $\mathrm{PC} 12$ cells were cultured on Matrigel in RPMI-1640 medium supplemented with 5\% HS, 2\% FBS and penicillin-streptomycin containing $100 \mathrm{ng} / \mathrm{ml} \mathrm{NGF}$ (mouse nerve growth factor $2.5 \mathrm{~S}$ grade
I, Alomone Labs) for 7-9 days. Medium was replaced every 2 days.

Different concentrations of $\mathrm{H}_{2} \mathrm{O}_{2}$ were tested in the oxidative stress injury model according to the previous studies $[25,26]$. Cell viability was assessed to determine the optimal $\mathrm{H}_{2} \mathrm{O}_{2}$ concentration. In our model, $0.3 \mathrm{mM} \mathrm{H}_{2} \mathrm{O}_{2}$ was considered the best concentration for the oxidative experiments. DNA-PK inhibitor NU7026 (Calbiochem) was diluted at $7.1 \mathrm{mM}$ and used for cell treatment at final concentration 10 $\mu \mathrm{M}$. Insulin was purchased from Sigma-Aldrich and used at the final concentration of $100 \mathrm{nM}$ for different incubation times (10-30 min).

We routinely checked our cell cultures and confirm it to be free of mycoplasma contamination by using "MycoStrip mycoplasma detection kit from Invivoen.

\section{Western blot analysis}

Protein extracts derived from cultures were subjected to determination of protein concentration by using the bicinchoninic acid kit (Micro BCA, Pierce). Appropriate amount of protein extracts was boiled for $5 \mathrm{~min}$ in SDS-PAGE Laemmli buffer (50 mM Tris-HCl, pH 6.8, 2\% SDS, $10 \%$ glycerol, $0.1 \%$ bromophenol blue, $50 \mathrm{mM}$ DTT) and separated by SDS-PAGE (5\% polyacrylamide for DNA-PKcs, $10 \%$ for Ku70, Ku86, AKT $\beta$-Actin and $\beta$-tubulin). Proteins were electrotransferred onto nitrocellulose membrane (HybondTM C-extra, Amersham Biosciences, UK limited) at $30 \mathrm{~V}$ overnight at $4{ }^{\circ} \mathrm{C}$ for DNA-PKcs and $100 \mathrm{~V}$ for $1 \mathrm{~h}$ at $4{ }^{\circ} \mathrm{C}$ for the other analyzed proteins. Membranes were blocked for $1 \mathrm{~h}$ at room temperature (RT) with $10 \%(\mathrm{w} / \mathrm{v})$ milk in TBS-T solution (blocking buffer, $0.1 \%$ Tween 20 in $1.3 \mathrm{M} \mathrm{NaCl}, 200 \mathrm{mM} \mathrm{KCl}, 250 \mathrm{mM}$ Tris- $\mathrm{HCl}, \mathrm{pH} 7.5)$ and incubated overnight at $4{ }^{\circ} \mathrm{C}$ with primary antibodies and then with the appropriate horseradish peroxidase-conjugated secondary antibody for $1 \mathrm{~h}$ at RT. Immunoreactive bands were detected by enhanced chemiluminescence detection system (EuroClone). The following primary antibodies were used: mouse DNA-PKcs Ab-4 mixture 1:400 (NeoMarkers MS423-P); goat anti Ku70 1:400 (Santa Cruz Biotechnology sc-1486); goat anti Ku86 1:500 (Santa Cruz Biotehnology sc-1484); Rabbit anti total AKT 1:1000 (Cell Signaling CST-9272); rabbit anti pospho Ser-473 AKT 1:1000 (Cell Signaling CST-9271 S); rabbit anti pospho Thr-308 AKT 1:1000 (Cell Signaling CST-9275 S); mouse anti anti- $\beta$ Actin 1:1000 (Sigma A3853); mouse anti $\beta$-tubulin 1:1000 (Sigma T8328); mouse anti $\gamma \mathrm{H} 2 \mathrm{AX}$ antibody 1:1000 (Millipore (Ser139), clone JBW301); rabbit anti-Caspase3 1:1000 (Cell Signaling CST-9662); rabbit anti-PARP-1 1:1000 (Cell Signaling CST-9542); rabbit anti total ERK 1:1000 (Cell Signaling CST-9102) and rabbit anti phospho-ERK (p42 and p44) 1:1000 (Cell Signaling CST-9101) in TBS-T containing 2 or $5 \%$ milk for $2 \mathrm{~h}$ or overnight at $4{ }^{\circ} \mathrm{C}$ with gentle shaking. 
After extensive washing in TBS-T, membranes were probed for $1 \mathrm{~h}$ at RT with Horseradish peroxidase-conjugated antibodies donkey anti-mouse IgG 1:100,000 (715-035-151) and anti-rabbit IgG 1:100,000 (711-035-152) (Jackson ImmunoResearch), anti-goat IgG 1:500,000 (sc-2768) (Santa Cruz Biotechnology) were used as secondary antibodies, diluited in TBS-T containing $2 \%$ milk and washed thoroughly with TBS-T. Blots were scanned and densitometric analysis was performed by using ImageQuant software (GE Healthcare). Protein loading was monitored by normalization to anti- $\beta$ Actin or $\beta$-Tubulin.

\section{Immunofluorescence analysis}

Immunofluorescence analysis was performed on proliferating and differentiated PC12 cells grown on matrigel-coated glass coverslips, fixed with phosphate buffer containing $4 \%$ paraformaldehyde and permeabilized with $0.2 \%$ Triton $\mathrm{X}-100$ to then be processed for immunofluorescence analysis according to [27]. Anti MAP2 antibody (1:500, Sigma) and mouse anti $\gamma \mathrm{H} 2 \mathrm{AX}$ antibody 1:500 (Millipore (Ser139), clone JBW301) were used as primary antibodies by incubation for $1 \mathrm{~h}$ at $37^{\circ} \mathrm{C}$ in $1 \times \mathrm{PBS}$ containing $0.05 \%$ Tween 20 and $3 \% \mathrm{BSA}$, followed by a $30 \mathrm{~min}$ incubation at $37^{\circ} \mathrm{C}$ with the secondary antibodies (Alexa 488, Alexa 568, Molecular Probes). Nuclei were counterstained with Hoechst and samples were mounted on glass slides and cover slipped with antifade glycerol mounting. For apoptotic cell detection, picnotic nuclei were counted and the percentage was calculated on the total cell number/field (10× objective) [28]. Images were acquired with an Eclipse 80i Nikon Fluorescence Microscope (Nikon Instruments, Amsterdam, Netherlands).

\section{Cell cycle and apoptosis by FACS analysis}

For cell cycle analysis PC12 cells were mechanically dissociated and resuspended in Nicoletti's buffer, containing $0.1 \%$ Sodium Citrate, $10 \mathrm{mM} \mathrm{NaCl}, 0.1 \%$ Triton X-100, $200 \mathrm{mg} / \mathrm{mL}$ Propidium Iodide (PI) and $200 \mathrm{mg} / \mathrm{mL}$ RNAse A [29]. Following $30 \mathrm{~min}$ incubation at room temperature cells were acquired with a FACSCanto flow cytometer (BD Biosciences).

\section{Statistical analysis}

Statistical analysis was conducted in $\mathrm{R}$ language ( $\mathrm{R}$ Core Team (2020). R: A language and environment for statistical computing. R Foundation for Statistical Computing, Vienna, Austria. URL https://www.R-project.org/). As a first step, normality and homoscedasticity were assessed using Shapiro-Wilk test (R function: shapiro.test()) and Levene's (R function: leveneTest(), "car" package), respectively. The assumptions showed to be met in our data set. Successively, significant differences between groups were evaluated with unpaired two-tailed t-test, one-way ANOVA and two-way ANOVA with interaction, depending on the specific experimental design as reported in the "Results" section. In case of significant omnibus tests, Tukey's Honestly-SignificantDifference (R function: TukeyHSD()) was applied for performing multiple pairwise-comparison between the means of groups. When two-way analyses were conducted and interaction was significant, main effects were not reported, whereas the complete post-hoc test results were shown in the figures. A significant difference was accepted at p-values below 0.05 .

\section{Results}

\section{$\mathrm{H}_{2} \mathrm{O}_{2}$ treatment of $\mathrm{PC} 12$ cells induces up-regulation of DNA-PK complex expression}

$\mathrm{H}_{2} \mathrm{O}_{2}$ is known to increase ROS production in cells, often leading to apoptosis and cell death [30, 31]. It has been shown that oxidative damage can cause nuclear and mitochondrial DNA damage, and can modulate expression of repair enzymes in neuronal cells $[32,33]$. DNA-PK complex kinase activity is regulated by different mechanisms, including modification in protein levels of the catalytic subunit DNA-PKcs and/or the regulatory subunits Ku70 and Ku86 [34-36].

To evaluate whether $\mathrm{H}_{2} \mathrm{O}_{2}$ can modulate DNA-PKcs protein levels in PC12 cells thus influencing DNA repair, we first treated proliferating PC12 cells with $\mathrm{H}_{2} \mathrm{O}_{2}$ at different concentrations and at different times. PC12 cells were exposed to concentrations of $\mathrm{H}_{2} \mathrm{O}_{2}$ in a range of $0.05-0.5 \mathrm{mM}$ for $1 \mathrm{~h}, 4$, and $24 \mathrm{~h}$ and then western blot analysis was performed on whole cell extracts. A two-way ANOVA showed a significant interaction between $\mathrm{H}_{2} \mathrm{O}_{2}$ concentrations and exposure time $[\mathrm{F}(8,45)=17.75, \mathrm{p}<0.001]$, thus meaning that DNA-PKcs protein levels were up-regulated in a $\mathrm{H}_{2} \mathrm{O}_{2}$ concentration-dependent manner with different profiles over time (Fig. 1). Particularly, post-hoc tests showed that $1 \mathrm{~h}$ exposure determines an increase of DNA-PKcs protein levels as $\mathrm{H}_{2} \mathrm{O}_{2}$ concentration grows; a step-like behavior was observed after $4 \mathrm{~h}$ exposure, with a plateau at higher $\mathrm{H}_{2} \mathrm{O}_{2}$ concentrations; for the $24 \mathrm{~h}$-treatment DNA-PKcs levels varied in a $\mathrm{H}_{2} \mathrm{O}_{2}$ concentration independent manner. Indeed, we observed a strong reduction (90\%) of DNA-PKcs levels at $24 \mathrm{~h}$ treatment with $0.05 \mathrm{mM}$ which was unexpected and inexplicably reproducible (Fig. 1). Moreover, $0.5 \mathrm{mM} \mathrm{H}_{2} \mathrm{O}_{2}$ treatment yielded the greatest effect both in acute $(1 \mathrm{~h})$ and chronic treatment $(24 \mathrm{~h})(250 \%$, and $220 \%$ increase respectively), differently from $4 \mathrm{~h}$-treatment that reached its maximum $(189 \%)$ already at $0.3 \mathrm{mM} \mathrm{H}_{2} \mathrm{O}_{2}$. We then analyzed whether treatment of $\mathrm{PC} 12$ cells with $\mathrm{H}_{2} \mathrm{O}_{2}$ was able to modulate protein levels of the DNA-PK complex 

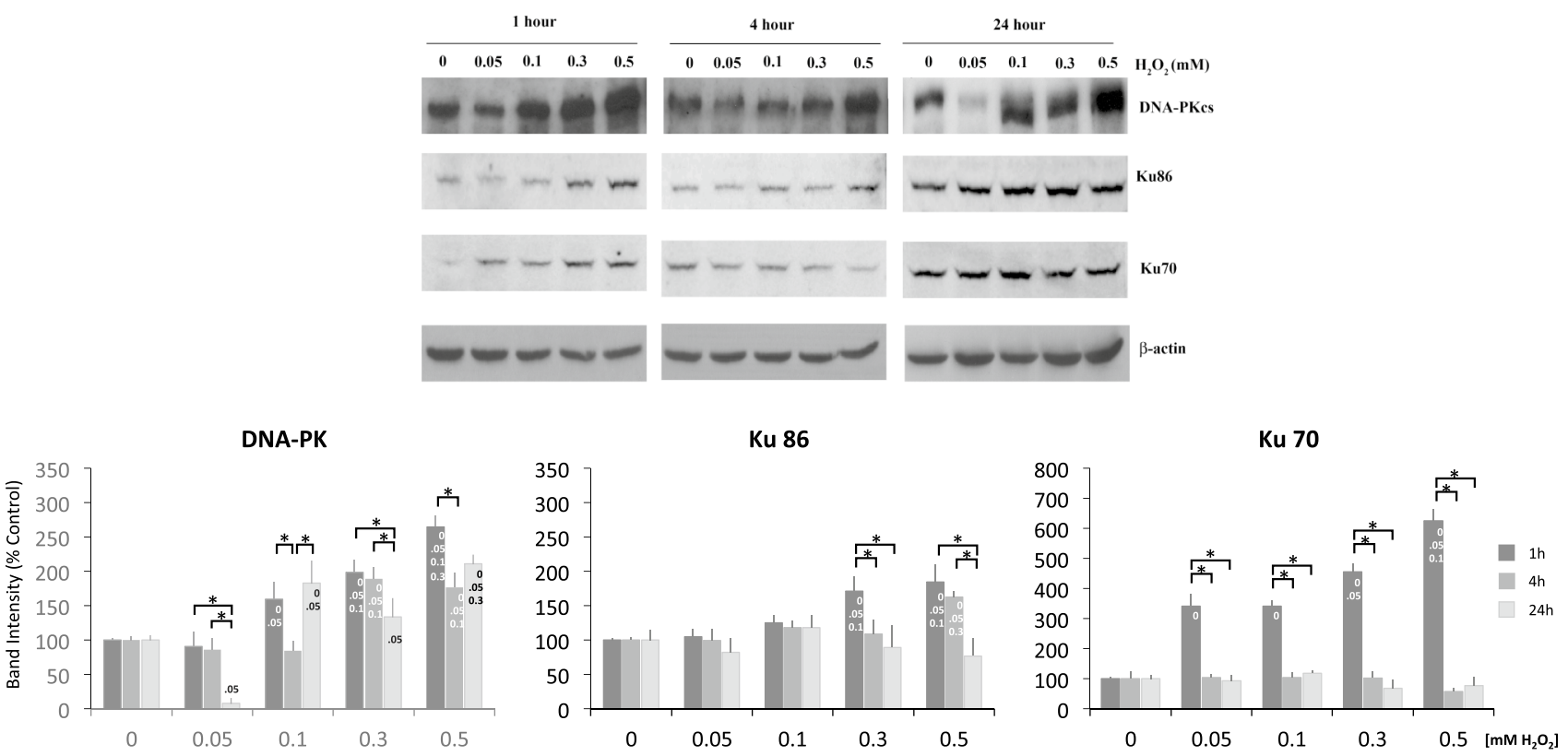

Fig. 1 Representative western blots of DNA-PKcs complex in PC12 cells treated for 1,4 , and $24 \mathrm{~h}$ with different $\mathrm{mM}$ doses of $\mathrm{H}_{2} \mathrm{O}_{2}$. After $\mathrm{H}_{2} \mathrm{O}_{2}$ incubation, cells were processed to obtain whole cellular extracts as described in "Materials and Methods" section and DNA$\mathrm{PKcs}, \mathrm{Ku} 86$ and $\mathrm{Ku} 70$ protein levels were assayed by western blot analysis. $\beta$-Actin was used as loading control. Densitometric quantitation of the immunoreactive bands corresponding to DNA-PKcs, $\mathrm{Ku} 70$ and Ku86 are represented in plots. Values in plots represent the

regulatory subunits, $\mathrm{Ku} 70$ and $\mathrm{Ku} 86$. In both cases we found a significant interaction between $\mathrm{H}_{2} \mathrm{O}_{2}$ concentrations and exposure time $[\mathrm{Ku} 86: \mathrm{F}(8,45)=8.50, \mathrm{p}<0.001 ; \mathrm{Ku} 70: \mathrm{F}(8$, $45)=101.13, p<0.001]$. Densitometric analysis of immunoreactive bands (Fig. 1) showed that only a short treatment ( $1 \mathrm{~h}$ ) could increase levels of both proteins in a $\mathrm{H}_{2} \mathrm{O}_{2}$ dose dependent manner.

These findings support the hypothesis that DNA-PK expression is induced rapidly after DNA damage with a mechanism that needs further investigation.

\section{$\mathrm{H}_{2} \mathrm{O}_{2}$ treatment induces DNA damage in PC12 cells which is repaired after recovery}

To analyze whether the upregulation of DNA-PK complex was associated with repairing of $\mathrm{H}_{2} \mathrm{O}_{2}$-mediated DNA damage, we chose the optimal dose of $0.3 \mathrm{mM}$ as the smallest dose inducing DNA-PK complex protein level increment ( $200 \%$ increase, $1 \mathrm{~h}$ treatment). We then evaluated the DNA damage and repair kinetics by monitoring the formation and disappearance of $\gamma \mathrm{H} 2 \mathrm{AX}$ foci, a well-known and sensitive molecular marker of DNA normalized percent changes in protein levels with respect to control (100\%) after exposure to $\mathrm{H}_{2} \mathrm{O}_{2}$. Results were representative of 5 independent experiments. [*] Significant differences $(\mathrm{p}<0.05)$ between time points within each concentration. [Concentration labels on bars] Significant differences $(\mathrm{p}<0.05)$ between concentrations $(0,0.05$, $0.1,0.3$, and 0.5 ) at the same time point, i.e. conc. labels are reported on a bar when a contrast between that group and any on its left is significant

damage, using immunofluorescence (Fig. 2). Cells having more than 10 foci/nucleus were scored positive. Left panel shows a representative immunofluorescence of $\gamma \mathrm{H} 2 \mathrm{AX}$ foci formation after $0.3 \mathrm{mM}$ of $\mathrm{H}_{2} \mathrm{O}_{2} 1 \mathrm{~h}$ treatment.

We then performed a kinetics of $\gamma \mathrm{H} 2 \mathrm{AX}$ dephosphorylation at different times after $\mathrm{H}_{2} \mathrm{O}_{2}$ removal, up to $24 \mathrm{~h}$, in which cells were maintained in fresh growing medium (condition defined as "Recovery" time). As it would be expected, a significant interaction was found between the effect of damage and the effect of exposure time on the amount of $\gamma \mathrm{H} 2 \mathrm{AX}$ positive cells $[\mathrm{F}(3,24)=119.45$, $\mathrm{p}<0.01$ ] (Fig. 2, right panel). Post hoc tests revealed that $0.3 \mathrm{mM} \mathrm{H}_{2} \mathrm{O}_{2}$ was able to induce a significant $75 \%$ increase ( $\mathrm{p}<0.001)$ of $\gamma \mathrm{H} 2 \mathrm{AX}$ positive cells as compared to control, $1 \mathrm{~h}$ after treatment (baseline). Successively, during the post-treatment repair time (Recovery), the percentage of $\gamma \mathrm{H} 2 \mathrm{AX}$ foci-positive cells gradually declined reaching the same levels as the untreated control cells $24 \mathrm{~h}$ after recovery (30\% of $\gamma \mathrm{H} 2 \mathrm{AX}$ foci positive cells, $\mathrm{p}=0.99$ ).

These results may suggest that after exposure to an oxidative damage, cells may respond by up-regulating DNA repair enzymes to overcome the injury. 


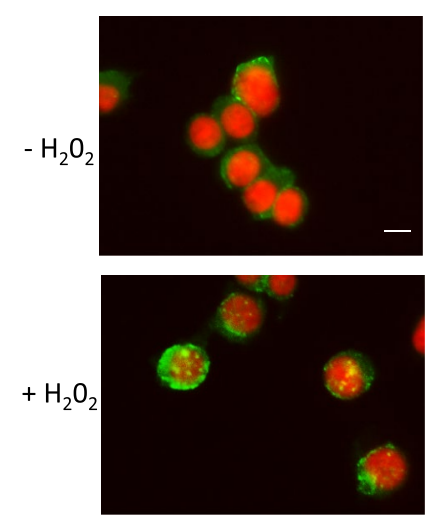

Fig. 2 Left Panel. Immunofluorescence images of proliferating PC12 cells in the absence or presence of $0.3 \mathrm{mM} \mathrm{H}_{2} \mathrm{O}_{2}$ treatment. Only cells exposed to $\mathrm{H}_{2} \mathrm{O}_{2}$ treatment show $\gamma \mathrm{H} 2 \mathrm{AX}$ positive foci (green) in nuclei counterstained with Hoechst (red). Scale bar, $5 \mu \mathrm{m}$. Right Panel. After exposure with $0.3 \mathrm{mM} \mathrm{H}_{2} \mathrm{O}_{2}$ for $1 \mathrm{~h}$ (baseline), $\mathrm{PC} 12$ cells were incubated for 4,8 , and $24 \mathrm{~h}$ with fresh $\mathrm{H}_{2} \mathrm{O}_{2}$-free medium (recovery condition). Cells were fixed and stained with anti- $\gamma \mathrm{H} 2 \mathrm{AX}$ antibody and subjected to immunofluorescence microscopy. The number of $\gamma \mathrm{H} 2 \mathrm{AX}$-positive cells were counted and plotted as his-

\section{Inhibition of DNA-PK kinase activity increases apoptosis without affecting DNA repair in proliferating PC12 cells}

To establish whether DNA-PK complex kinase activity has a role in DNA repair following $\mathrm{H}_{2} \mathrm{O}_{2}$, we performed experiments in presence of NU7026 $(10 \mu \mathrm{M})$, a specific DNA-PK kinase inhibitor. Figure $3 \mathrm{~A}$ shows that after $0.3 \mathrm{mM} \mathrm{H} \mathrm{H}_{2}$ treatment, $\mathrm{PC} 12$ cells accumulate $\gamma \mathrm{H} 2 \mathrm{AX}$ foci $(69 \%, t(6)=11.45, p<0.001)$. After $24 \mathrm{~h}$ recovery, differences in means between untreated, $\mathrm{H}_{2} \mathrm{O}_{2}$-treated, NU7026-added cells were not significant $[F(3,9)=3.059$, $\mathrm{p}=0.096]$. PC12 cells repaired foci both in the absence and presence of NU7026 inhibitor, indicating that other DNAPK independent repair mechanisms may be operative in proliferating PC12 cells. Western blot analysis of protein levels of $\gamma \mathrm{H} 2 \mathrm{AX}$ confirmed the presence of DNA damage following $1 \mathrm{~h} 0.3 \mathrm{mM} \mathrm{H}_{2} \mathrm{O}_{2}$ treatment, that decreased after recovery both in absence and presence of DNA-PK inhibitor (Fig. 3B).

We also evaluated the percentage of apoptotic cells after $0.3 \mathrm{mM} \mathrm{H}_{2} \mathrm{O}_{2} 1 \mathrm{~h}$ treatment (Fig. $3 \mathrm{C}$ ). After $24 \mathrm{~h}$ recovery, the percentage of apoptotic cells significantly varied with cell conditions $[F(3,9)=52.74, p<0.001]$; pairwise comparisons were thus evaluated with post hoc tests. Figure $3 \mathrm{C}$ shows that $\mathrm{H}_{2} \mathrm{O}_{2}$ treatment caused a $30 \%$ of apoptotic cells $(\mathrm{p}<0.001)$ during recovery. This amount further increased in the presence of $10 \mu \mathrm{M}$ NU7026 by approx. $15 \%$ as compared with $\mathrm{H}_{2} \mathrm{O}_{2}$-treated cells $(\mathrm{p}=0.019)$. This result was surprising because, in the same conditions, DNA damage was repaired as indicated by the return to basal level



tograms to show the repair kinetics of damaged DNA. After $24 \mathrm{~h}$ recovery, DNA damages are completely repaired. Results were representative of 5 independent experiments. [*] Significant differences $(\mathrm{p}<0.05)$ between $+/-\mathrm{H}_{2} \mathrm{O}_{2}$ conditions at each time point. [Time labels on bars] Significant differences $(\mathrm{p}<0.05)$ between time points ( $1 \mathrm{~h}, 4 \mathrm{~h}, 8 \mathrm{~h}$, and $24 \mathrm{~h}$ ) in the same $\mathrm{H}_{2} \mathrm{O}_{2}$ condition, i.e. time labels are reported on a bar when a contrast between that group and any on its left is significant. (Color figure online)

of $\gamma \mathrm{H} 2 \mathrm{AX}$ foci (Fig. 3A) and suggests a protective role of DNA-PK under oxidative stress conditions.

In addition, we confirmed the occurrence of apoptosis after $0.3 \mathrm{mM} \mathrm{H}_{2} \mathrm{O}_{2} 1 \mathrm{~h}$ treatment and following $24 \mathrm{~h}$ recovery both in the presence ad absence of $10 \mu \mathrm{M}$ NU7026 by FACS analysis (Fig. 3D).

Because post-mitotic cells adopt mainly NHEJ to repair damaged DNA [37, 38], we evaluated the effect of $\mathrm{H}_{2} \mathrm{O}_{2}$ $4 \mathrm{~h}$ treatment on NGF-differentiated PC12 cells (Fig. 4), a well-known neuronal model [39-42], and $\gamma \mathrm{H} 2 \mathrm{AX}$ foci were counted after $24 \mathrm{~h}$ recovery (Fig. $4 \mathrm{~B}$ ). We found that untreated control cells showed about $4 \%$ of nuclei positive to $\gamma \mathrm{H} 2 \mathrm{AX}$. $4 \mathrm{~h}$ of exposure to $\mathrm{H}_{2} \mathrm{O}_{2}$ induced foci accumulation in $65 \%$ of nuclei $[\mathrm{t}(6)=40,278, \mathrm{p}<0.01]$. Analysis of variance showed a significant effect of $24 \mathrm{~h}$ recovery on the amount of $\gamma \mathrm{H} 2 \mathrm{AX}$ positive cells $[\mathrm{F}(3,12)=540.2, \mathrm{p}<0.01]$. The presence of $10 \mu \mathrm{M}$ NU7026 DNA-PK inhibitor, significantly decreased the ability to repair DNA damage, such that $60 \%$ of cells remained positive to $\gamma \mathrm{H} 2 \mathrm{AX}(\mathrm{p}<0.001)$, and will likely undergo cell death (Fig. 4B). Western blot analysis of protein levels of $\gamma \mathrm{H} 2 \mathrm{AX}$ confirmed the presence of DNA damage following $4 \mathrm{~h} 0.3 \mathrm{mM} \mathrm{H}_{2} \mathrm{O}_{2}$ treatment, that decreased after recovery only in the absence of DNA-PK inhibitor (Fig. 4 C).

Overall these experiments support an anti-apoptotic role of DNA-PK independent of its DNA repair activity in proliferating cells where different DNA repair mechanisms operate. On the contrary, in neuronal cells, where DNA damage (specifically DSBs) is mostly repaired by NHEJ, the repair activity of DNA-PK complex may play a pivotal role in cell viability. 
A

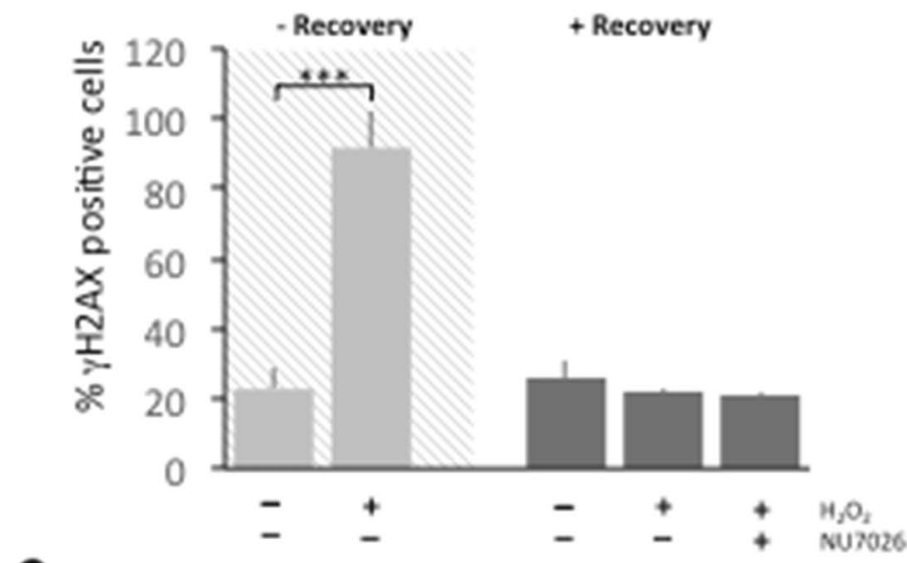

C

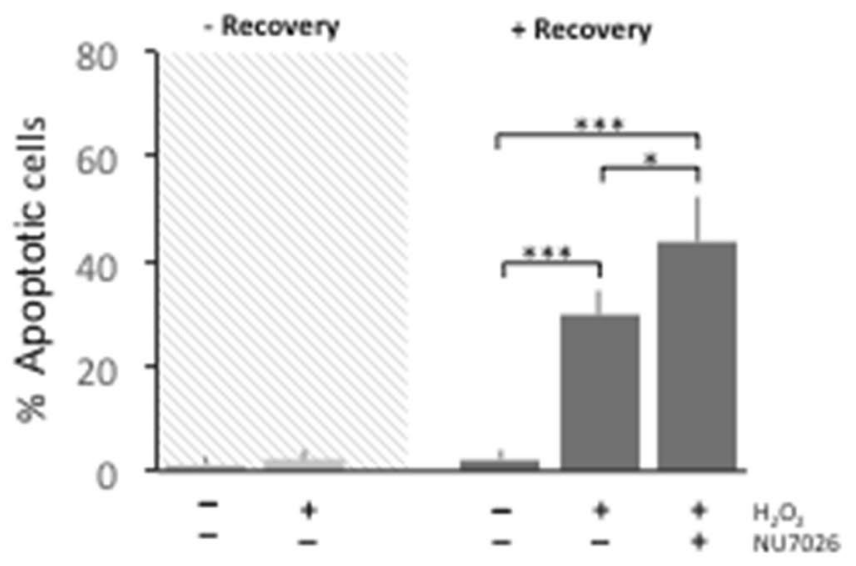

B
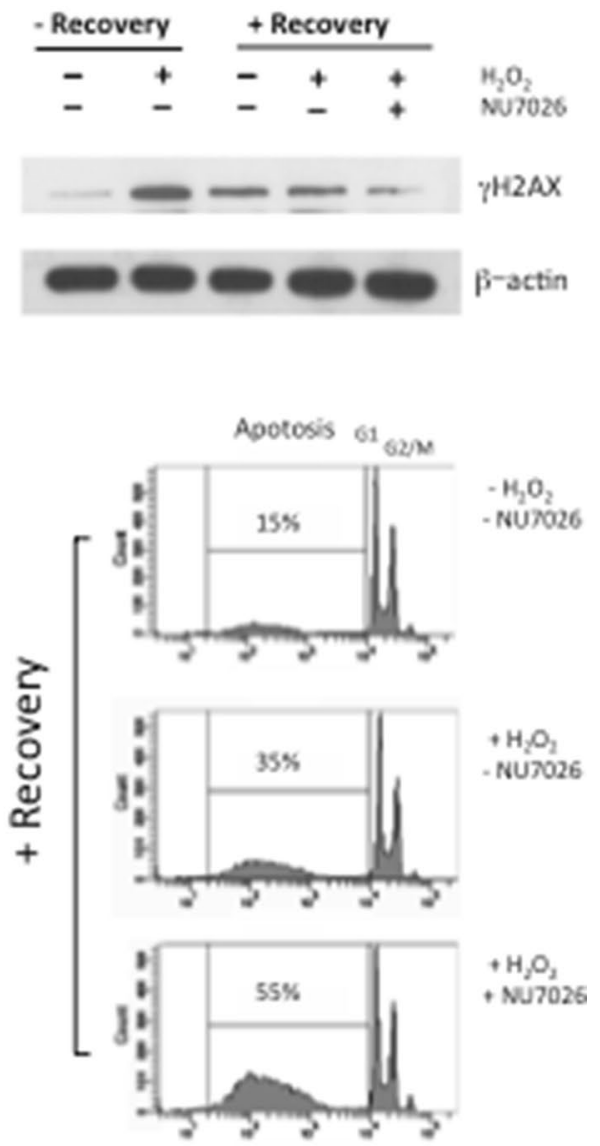

Fig. 3 PC12 cells were treated for $1 \mathrm{~h}$ with $0.3 \mathrm{mM} \mathrm{H}_{2} \mathrm{O}_{2}$ and then incubated for $24 \mathrm{~h}$ with fresh medium with or without NU7026 $(10 \mu \mathrm{M})$, a potent DNA-PK inhibitor. Cells were fixed and stained with anti- $\gamma \mathrm{H} 2 \mathrm{AX}$ antibody to count foci and nuclei were counterstained with Hoechst to count condensed and/or fragmented nuclei as apoptotic cells. A Bar chart showing that $\gamma \mathrm{H} 2 \mathrm{AX}$ foci are repaired after a $24 \mathrm{~h}$ recovery even if DNA-PK activity is inhibited. As supplementary information, percentage foci without recovery (grey background) are reported to show the increase after $\mathrm{H}_{2} \mathrm{O}_{2}$ treatment. B Representative western blots of $\gamma \mathrm{H} 2 \mathrm{AX}$ in PC12 cells treated for $1 \mathrm{~h}$ with $0.3 \mathrm{mM}$ of $\mathrm{H}_{2} \mathrm{O}_{2}$ confirming the repair of DNA damage both in presence and absence of DNA-PK inhibitor during recovery. After $\mathrm{H}_{2} \mathrm{O}_{2}$ incubation, cells were processed to obtain whole cell extracts as described in "Materials and Methods" section. $\beta$-actin was used as loading control. Image is representative of 3 independ-

\section{The anti-apoptotic function of DNA-PK under oxidative stress conditions is associated with AKT phosphorylation of Serine 473 in PC12 cells}

It is known that severe DNA damage induces the activation of apoptosis and signals of phosphorylation of other proteins are activated and transduced. To study the molecular ent experiments. $\mathbf{C}$ Bar chart showing that $0.3 \mathrm{mM} \mathrm{H}_{2} \mathrm{O}_{2}$ treatment caused a $30 \%$ of apoptotic cells after $24 \mathrm{~h}$ recovery. A further increase is observed in the presence of $10 \mu \mathrm{M}$ NU7026, as compared with $\mathrm{H}_{2} \mathrm{O}_{2}$-treated cells ( $+15 \%$ ). In addition, without repair (grey background) $\mathrm{H}_{2} \mathrm{O}_{2}$ treatment did not induce augmented apoptosis $(\mathrm{p}=38)$. Bars in the plot represent mean \pm S.D. of apoptotic cells expressed as percentage. D FACS analysis was conducted to confirm the occurrence of apoptosis after $0.3 \mathrm{mM} \mathrm{H}_{2} \mathrm{O}_{2} 1 \mathrm{~h}$ treatment followed by $24 \mathrm{~h}$ recovery both in the presence ad absence of $10 \mu \mathrm{M}$ NU7026. Cells were stained with PI, according to Nicoletti's protocol. Histograms show DNA content distribution in the different experimental conditions and indicate an increase of approx. $20 \%$ in apoptotic cells in the presence of DNA-PK inhibitor. Apoptotic cells appear with fractional DNA content before the peak of G1 cells

mechanism underlying the anti-apoptotic function of DNAPK complex in proliferating PC12 cells exposed to oxidative stress, we performed western blot analysis on whole cell extracts looking at the expression of several key proteins involved in the apoptotic pathway (i.e. AKT, Caspase 3 and PARP). The serine/threonine protein kinase $\mathrm{B}$ (PKB), also known as AKT, is a downstream effector of phosphatidylinositol 3-kinase (PI3K) and a major regulator of a variety of 
A

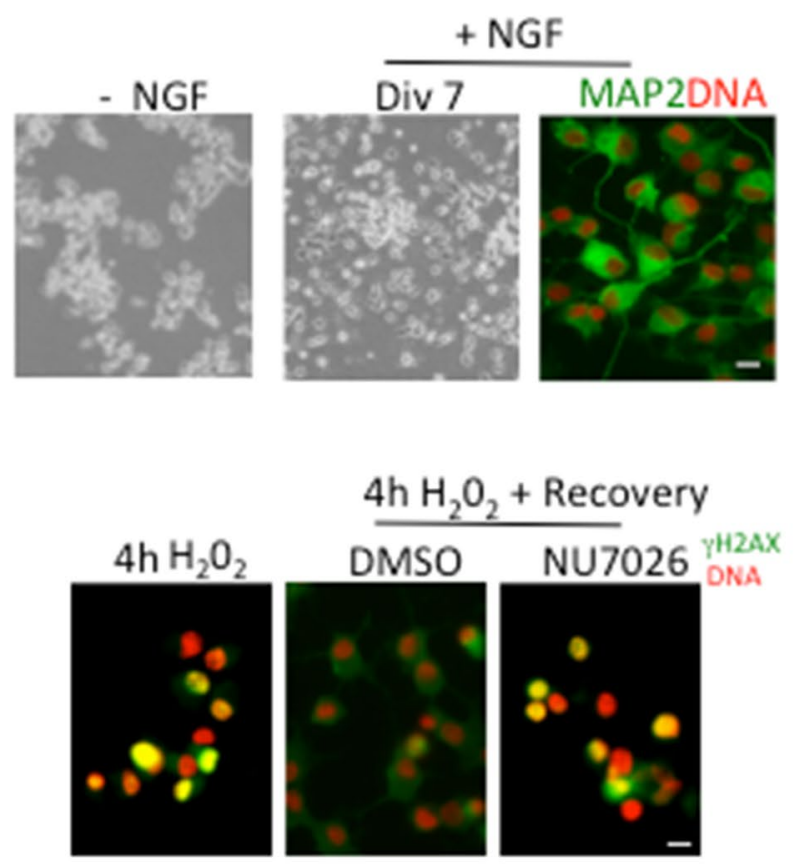

Fig. 4 A Proliferating PC12 cells were differentiated with NGF for 7 days to be then exposed to $\mathrm{H}_{2} \mathrm{O}_{2}$ followed by a recovery in fresh medium. Cells were then fixed and immunolabelled for $\gamma \mathrm{H} 2 \mathrm{AX}$ foci detection. Upper panel. A microscopic field of proliferating PC12 cells in the absence of NGF showing a circular morphology and a field of PC12 cells after NGF treatment with a typical neuronal morphology, are shown in phase contrast images. After 7 days of NGF treatment, PC12 cells acquire neuronal features as indicated by the labelling with MAP2 (green) and DNA (red). Lower panel. Immunofluorescence of NGF-differentiated PC12 cells exposed to $0.3 \mathrm{mM}$ $\mathrm{H}_{2} \mathrm{O}_{2}$ for $4 \mathrm{~h}$ followed by a $24 \mathrm{~h}$ recovery in fresh medium. Immunolabelled cells show the presence of $\gamma \mathrm{H} 2 \mathrm{AX}$ foci after exposure to $\mathrm{H}_{2} \mathrm{O}_{2}$ (green). During recovery, differentiated PC12 cells maintain $\gamma \mathrm{H} 2 \mathrm{AX}$ foci (green) in the presence of NU7026 as compared to control cells.

cellular processes, including metabolism, transcription, antiapoptotic, proliferation, and growth [43, 44]. Activation of AKT requires phosphorylation at two key regulatory sites as follows: Thr-308 and Ser-473, the second one within a C-terminal hydrophobic motif, leads to full activation of AKT [45, 46].

We compared AKT phosphorylation pattern of PC12 cells treated with increasing $\mathrm{H}_{2} \mathrm{O}_{2}$ concentrations, ranging from 0.1 to $0.5 \mathrm{mM}$, without pre-treatment with NU7026 or with a $24 \mathrm{~h}$ incubation with $10 \mu \mathrm{M}$ NU7026 (Fig. 5A). To this aim a two-way ANOVA was conducted on protein phosphorylation by NU7026-treatment and by $\mathrm{H}_{2} \mathrm{O}_{2}$ concentrations. Significant interactions were found for Ser- $473[\mathrm{~F}(3$, $24)=3.43, p<0.001]$; successively post hoc tests were run. As shown in Fig. 5A, western blots of whole cell extracts of
B

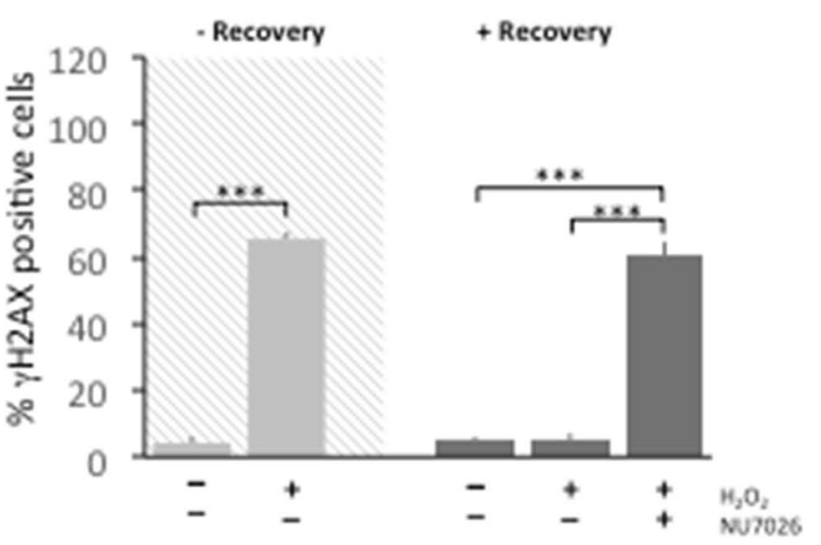

C



Scale bar, $5 \mu \mathrm{m}$. B Bar chart showing that in NGF-differentiated PC12 cells exposed to $0.3 \mathrm{mM} \mathrm{H}_{2} \mathrm{O}_{2}$ for $4 \mathrm{~h}$ followed by a $24 \mathrm{~h}$ recovery in fresh medium, $\gamma \mathrm{H} 2 \mathrm{AX}$ foci are not repaired in presence of DNA-PK inhibitor, NU7026 ( $+55 \%$, vs. $\mathrm{H}_{2} \mathrm{O}_{2}$-treated, $\left.\mathrm{p}=0.015\right)$. For completeness, without recovery the effect of $\mathrm{H}_{2} \mathrm{O}_{2}$-damage is shown (Mdiff $=61 \%, t(6)=40.27, \mathrm{p}<0.001$ ). Bars in the plots represent mean \pm S.D. of cells expressed as percentage. $* \mathrm{p}<0.05 ; * * * \mathrm{p}<0.001$. C Representative western blots of $\gamma \mathrm{H} 2 \mathrm{AX}$ in differentiated PC12 cells treated for $4 \mathrm{~h}$ with $0.3 \mathrm{mM}$ of $\mathrm{H}_{2} \mathrm{O}_{2}$ confirming the maintenance of DNA damage in presence of DNA-PK inhibitor during recovery. After $\mathrm{H}_{2} \mathrm{O}_{2}$ incubation, cells were processed to obtain whole cell extracts as described in "Materials and Methods" section. $\beta$-tubulin was used as loading control. Image is representative of 3 independent experiments. (Color figure online)

PC12 cells in the absence of NU7026 pre-treatment showed that all the $\mathrm{H}_{2} \mathrm{O}_{2}$ tested concentrations are capable to induce a strong increase of phosphorylated Ser-473AKT levels (25 fold as compared to control cells treated with $0.5 \mathrm{mM} \mathrm{H}_{2} \mathrm{O}_{2}$, $\mathrm{p}<0.001$ ), while no significant alteration was observed for the phosphorylation in Thr-308 (data not shown). Differently, western blot analysis of protein extracts from NU7026 pre-treated $\mathrm{PC} 12$ cells $24 \mathrm{~h}$ before $\mathrm{H}_{2} \mathrm{O}_{2}$ exposure, showed a strong reduction of AKT phosphorylation of Ser-473 (38\% reduction NU7026 treated cells at $0.1 \mathrm{mM} \mathrm{H}_{2} \mathrm{O}_{2} ; 57 \%$ reduction NU7026 treated cells at $0.3 \mathrm{mM} \mathrm{H}_{2} \mathrm{O}_{2} ; 39 \%$ reduction NU7026 treated cells at $0.5 \mathrm{mM} \mathrm{H}_{2} \mathrm{O}_{2}, \mathrm{p}<0.01$ in all cases). These results suggest a major anti-apoptotic role of DNA-PK that involves AKT phosphorylation in Ser-473. To verify the specificity of DNA-PK function in AKT regulation after 
A
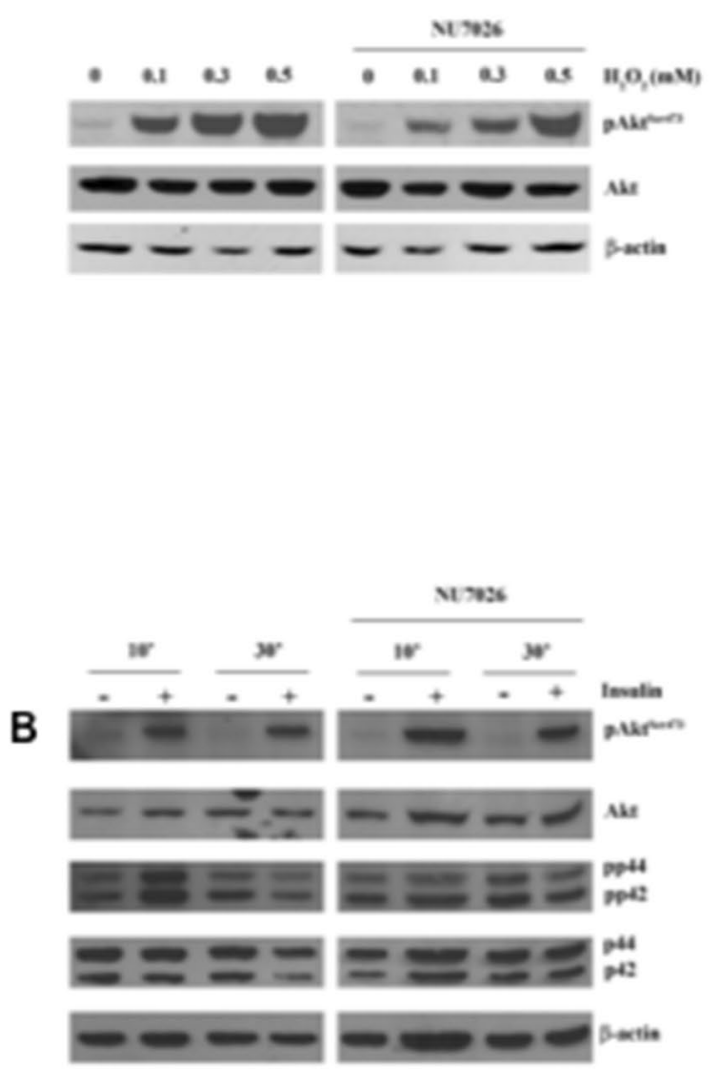



C



Fig. 5 Western blot analysis of AKT phosphorylation in proliferating PC12 cells pre-exposed for $24 \mathrm{~h}$ with $10 \mu \mathrm{M}$ NU7026 and then incubated for $30 \mathrm{~min}$ with different doses of $\mathrm{H}_{2} \mathrm{O}_{2}$ (A) or for 10 and $30 \mathrm{~min}$ with $100 \mathrm{nM}$ insulin (B). C Analysis of full length and cleaved Caspase- 3 and cleaved-PARP-1 protein levels in PC12 cells pre-treated for $24 \mathrm{~h}$ with NU7026 and for 30 min with 0.5 and $1 \mathrm{mM}$

oxidative stress, we tested another stimulus known to induce Ser-473 AKT phosphorylation such as insulin treatment. Cells were exposed to insulin treatment $(100 \mathrm{mM})$ for 10 or $30 \mathrm{~min}$ and whole cell extracts analyzed for Ser-473 AKT phosphorylation in absence or presence of DNA-PK inhibitor. As shown in Fig. 5B, insulin induces Ser-473 AKT phosphorylation (both after 10 and $30 \mathrm{~min}$ treatment) which is not affected by DNA-PK kinase activity inhibition, indicating that DNA-PK is not involved in the activation of downstream effector AKT following insulin treatment. Similarly, DNAPK, upon insulin treatment, is not essential for the ERK (p44 and p42) phosphorylation activation in PC12 cells (Fig. 5B).

The induction of apoptosis is associated with activation of aspartate-specific cysteine proteases (Caspases) that are present as inactive zymogens containing an N-terminal prodomain and large and small catalytic subunits. Caspases are activated either by autocatalytic processing and/or cleavage
$\mathrm{H}_{2} \mathrm{O}_{2}$. Results were representative of 5 independent experiments. [*] Significant differences $(p<0.05)$ between NU7026 conditions within each concentration. [Concentration labels on bars] Significant differences $(p<0.05)$ between concentrations $(0,0.1,0.3,0.5)$ in the same NU7026 conditions, i.e. conc. labels are reported on a bar when a contrast between that group and any on its left is significant

by other caspases at internal Asp residues following a variety of death stimuli, including oxidative DNA [47].

We found that following $\mathrm{H}_{2} \mathrm{O}_{2}$ treatment PC12 cells undergo apoptosis mediated by the activation of Caspase- 3 cleavage (Fig. 5C). Interestingly, a $24 \mathrm{~h}$ treatment of cells with $10 \mu \mathrm{M}$ NU7026, a concentration that blocks DNA-PK activity, increased Caspase-3 processing (Fig. 5C), supporting a protective role of DNA-PK under oxidative stress conditions. Caspase-mediated apoptotic cell death is accomplished through the cleavage of several key proteins required for cellular functioning and survival [48], including PARP-1 whose cleavage is considered to be a hallmark of apoptosis [49]. By western blot we observed, along with Caspase-3 activation, an increase in the cleaved PARP-1 (Fig. 5C).

Thus, DNA-PK exerts an anti-apoptotic function associated with Caspase-3 processing, which is further increased when DNA-PK activity is inhibited by NU7026 (Fig. 5C). 
Collectively, these experiments showed that DNA-PKmediated anti apoptotic function, upon $\mathrm{H}_{2} \mathrm{O}_{2}$-dependent oxidative stress, is associated with AKT phosphorylation in Ser-473 and involves the processing of Caspase-3 signalling cascade.

\section{Discussion}

DNA repair represents a strategy to overcome the DNA damages accumulated by the cells upon exposure to different agents. Whenever DNA damage is too extensive, the DDR pathway can trigger cellular senescence and/or apoptosis $[50,51]$. Among a wide range of possible DNA lesions, oxidized bases and DNA single strand breaks (SSBs) are the most common [52]. However, DNA DSBs are the most lethal form of DNA damage which, if left unrepaired, can induce a prominent loss of genetic material and ultimately cell death. Misrepaired DSBs are also deleterious because of their capability to cause genomic rearrangements, mutagenesis and more in general genomic (or mitochondrial) instability. These events are more critical in neurons, because they have a reduced DNA repair ability and a slower rate of DNA repair compared to proliferating cells, as for other differentiated cells [53, 54].

DSBs are repaired in neurons by the NHEJ pathway that relies on the DNA-dependent protein kinase complex [55].

In this study we evaluated the role of DNA-PK in oxidative stress response by using the PC12 cell model, a wellknown neuronal cell line. In particular, we studied the effect of oxidative stress on DNA-PK complex expression levels and activity both in proliferating and differentiated PC12 cells. In addition, we assessed a possible dual role of DNA$\mathrm{PK}$ as repair enzyme and an anti-apoptotic factor.

We found that: (i) $\mathrm{H}_{2} \mathrm{O}_{2}$ treatment of $\mathrm{PC} 12$ cells induces up-regulation of DNA-PK complex protein levels; (ii) inhibition of DNA-PK kinase activity, by using the selective DNA-PK inhibitor NU7026, increases apoptosis without affecting DNA repair in proliferating PC12 cells; (iii) the anti-apoptotic role of DNA-PK is independent of its DNA repair activity in proliferating cells, however, in neuronal cells, where DSBs are mostly repaired by NHEJ, the inhibition of DNA-PK activity causes an accumulation of DNA damage which would probably lead to cell death; (iv) DNAPK anti apoptotic function is associated with AKT phosphorylation in Ser- 473 and involves the processing of Caspase- 3 signalling cascade.

This study shows that $\mathrm{H}_{2} \mathrm{O}_{2}$, at biologically relevant concentrations that are found in cells during acute and chronic inflammation processes, causes a marked increase in $\gamma \mathrm{H} 2 \mathrm{AX}$ foci, hallmark of DNA breaks, along with a significant elevation in the expression of DNA-PKcs and its regulatory subunits $\mathrm{Ku} 70$ and $\mathrm{Ku} 86$. It is likely that the observed induction of DNA-PK complex is required to counteract oxidative stress response that would otherwise lead to DNA damage and decreased in cell viability. Further studies will be required to unveil the mechanisms inducing the rapid DNAPK expression increase after DNA damage.

Further, we showed that $\mathrm{PC} 12$ cells accumulate $\gamma \mathrm{H} 2 \mathrm{AX}$ foci that are repaired after a $24 \mathrm{~h}$ recovery both in the absence and presence of the DNA-PK inhibitor NU7026, indicating that other DNA-PK independent repair mechanisms may be involved. Indeed, proliferating cells possess other DNA repair systems such as the HR that can guarantee further genome stability [56]. Remarkably, while the capacity to repair $\gamma \mathrm{H} 2 \mathrm{AX}$ foci is maintained in proliferating PC12 cells after $24 \mathrm{~h}$ recovery, inhibition of DNA-PK complex activity determines an increase in the percentage of apoptotic cells, indicating an additional role of DNA-PK as an anti-apoptotic agent.

The fact that DNA-PK might possess multiple functions is in line with other studies showing that this kinase has some unusual properties. For example, its high cellular concentration [57], its presence both in the nucleus and in the cytoplasm [58], far in excess of what is probably needed for NHEJ function.

ROS generation is known to cause DNA lesions, both SSBs and DSBs and accumulation of DNA damage may represent a great concern for cells that do not replicate, such as terminally differentiated neurons. In fact, DNA damage caused by $\mathrm{H}_{2} \mathrm{O}_{2}$ in neurons, that have high levels of transcription and oxidative stress, may misdirect them to re-enter cell cycle albeit unsuccessfully, which in turn can lead to accumulation of excessive DNA damage causing neuronal death. Indeed, we show that differentiated PC12 cells, likewise post-mitotic neurons, upon exposure to $\mathrm{H}_{2} \mathrm{O}_{2}$, are not able to repair lesions in presence of DNA-PK inhibitor and may undergo cell death. This idea is also supported by the observation that in migrating cortical neurons oxidative DNA damage is normally repaired by NHEJ and failure in the repairing machinery triggers neuronal apoptosis [59]. Our data presented here may be important in understanding the roles of DNA repair enzymes and the mechanisms maintaining genomic stability in non-proliferating cells.

Moreover, we have previously demonstrated that in PC12 cells aggregated $\beta$-amyloid impairs DNA-PK activity mainly through ROS production [34]. Hence, it is possible that exposure to oxidative injuries in the presence of of amyloidogenic proteins, such as $\beta$-amyloid in Alzheimer's Disease and huntingtin protein in Huntington Disease, elicits neuronal cell death by inhibition of DNA-PK anti-apoptotic function, leading to neurodegeneration.

It is known that DNA-PK can regulate AKT Ser-473 phosphorylation [45, 60, 61]. Moreover, Surucu et al. demonstrated that DNA-PK phosphorylates AKT Ser-473 upon induction of DNA DSBs [62]. However, the regulation of 
AKT by DNA-PK under oxidative conditions remained to be established. Here we show that $\mathrm{H}_{2} \mathrm{O}_{2}$ treated proliferating PC12 cells, following DNA-PK inhibition, undergo apoptosis, as shown by the cleavage of Caspase- 3 and its target PARP-1, and this death signalling is associated with the phosphorylation of AKT in Ser-473. Differently, DNA-PK activation following $\mathrm{H}_{2} \mathrm{O}_{2}$ treatment does not affect AKT phosphorylation in Thr-308. This differences in residues phosphorylation is in agreement with previous observations showing that DNA-PK directly phosphorylates AKT on Ser-473 in vitro and its activity in cells is potently inhibited by LY-294002 and wortmannin, two PI3K-specific inhibitors [63]. In addition, AKT phosphorylation at Ser-473 was greatly diminished in DNA-PKcs short interfering (si)RNA-treated cells, and DNA-PKcsdeficient cells [64]. Furthermore, we showed that DNA-PK is unlikely to be a physiological upstream kinase mediating AKT phosphorylation upon insulin treatment, while its kinase activity has AKT as major target under oxidative stress conditions.

Other than its essential role in NHEJ, because DNA-PK is also a critical player in cell survival/death and gene transcription, it is compelling to suggest that DNA-PK can have distinct and independent functions critical for cellular homeostasis. These different roles, that deserve further analysis, may be dependent on variations in the cell cycle status, and the abundance of DNA-PKcs in different tissues.

Oxidative stress is linked to a long diverse list of human diseases including neurodegeneration and cancer. Indeed, the inhibition of DNA-PK is a very promising target in anticancer research since the efficacy of radiotherapy and some chemotherapies, working by inducing DNA DSBs in tumor cells, can be compromised by the efficient repair of DNA damage through activation DNA-PK [65].

Oxidative stress has also been suggested as the possible cause behind the inevitable process of aging, thus, identification and understanding of the key factors responsible for DNA repair and their multiple functions can unveil potential intervention points of human pathologies caused by oxidative stress.

In conclusion, our findings provide insight into the pathophysiological mechanisms underlying oxidative stress damage and suggest innovative and effective treatments for ROS-related diseases, exploiting DNA-PK-based therapeutics and/or compounds able to activate DNA-PK function.

Author contributions Conceptualization and design of experiments, $\mathrm{AC}, \mathrm{CM}$ and DM; cellular experiments SS, LL and CDD; molecular experiments SS, LL and MP; data acquisition and analysis SS and LL; data analysis and interpretation AC, EG, CM and DM; statistical analysis IR; drafting of the manuscript $\mathrm{CM}$ and DM; critical revision of the manuscript AC, FS, EG, CM and DM; supervision DM. All authors have read and agreed to the published version of the manuscript.
Funding This research is supported by funds from Italian Ministry of Health (Grant No. Ricerca Corrente 2020 to L.L. and D.M.) and from Italian Ministry of University and Research, project title: "Nuovi Biomarker Diagnostici e Terapeutici delle Malattie Neurodegenerative", Grant No. FOE2020 to D.M.

\section{Declarations}

Conflict of interest The authors declare no conflict of interest.

Ethical approval This article does not contain any studies with human participants or animals performed by any of the authors.

Open Access This article is licensed under a Creative Commons Attribution 4.0 International License, which permits use, sharing, adaptation, distribution and reproduction in any medium or format, as long as you give appropriate credit to the original author(s) and the source, provide a link to the Creative Commons licence, and indicate if changes were made. The images or other third party material in this article are included in the article's Creative Commons licence, unless indicated otherwise in a credit line to the material. If material is not included in the article's Creative Commons licence and your intended use is not permitted by statutory regulation or exceeds the permitted use, you will need to obtain permission directly from the copyright holder. To view a copy of this licence, visit http://creativecommons.org/licenses/by/4.0/.

\section{References}

1. Cross CE, Halliwell B, Borish ET, Pryor WA, Ames BN, Saul RL, McCord JM, Harman D (1987) Oxygen radicals and human disease. Ann Intern Med 107:526-545. https://doi.org/10.7326/ 0003-4819-107-4-526

2. Sies H (1991) Oxidative stress: from basic research to clinical application. Am J Med 91:31S-38S. https://doi.org/10.1016/00029343(91)90281-2

3. Cooke MS, Evans MD, Dizdaroglu M, Lunec J (2003) Oxidative DNA damage: mechanisms, mutation, and disease. FASEB J 17:1195-1214. https://doi.org/10.1096/fj.02-0752rev

4. Hoeijmakers JH (2009) DNA damage, aging, and cancer. N Engl J Med 361:1475-1485. https://doi.org/10.1056/NEJMra0804615

5. Chapman JR, Taylor MR, Boulton SJ (2012) Playing the end game: DNA double-strand break repair pathway choice. Mol Cell 47:497-510. https://doi.org/10.1016/j.molcel.2012.07.029

6. Liu Y, Li Y, Lu X (2016) Regulators in the DNA damage response. Arch Biochem Biophys 594:18-25. https://doi.org/10.1016/j.abb. 2016.02.018

7. Wyman C, Ristic D, Kanaar R (2004) Homologous recombination-mediated double-strand break repair. DNA Repair (Amst) 3:827-833. https://doi.org/10.1016/j.dnarep.2004.03.037

8. Helleday T, Lo J, van Gent DC, Engelward BP (2007) DNA double-strand break repair: from mechanistic understanding to cancer treatment. DNA Repair (Amst) 6:923-935. https://doi.org/ 10.1016/j.dnarep.2007.02.006

9. Lieber MR (2010) The mechanism of double-strand DNA break repair by the nonhomologous DNA end-joining pathway. Annu Rev Biochem 79:181-211. https://doi.org/10.1146/annurev.bioch em.052308.093131

10. Smith GC, Jackson SP (1999) The DNA-dependent protein kinase. Genes Dev 13:916-934. https://doi.org/10.1101/gad.13.8.916

11. Finnie NJ, Gottlieb TM, Blunt T, Jeggo PA, Jackson SP (1996) DNA-dependent protein kinase defects are linked to deficiencies 
in DNA repair and V(D)J recombination. Philos Trans R Soc Lond B Biol Sci 351:173-9. https://doi.org/10.1098/rstb.1996.0014

12. Lee $\mathrm{SH}$, Kim CH (2002) DNA-dependent protein kinase complex: a multifunctional protein in DNA repair and damage checkpoint. Mol Cells 13:159-166

13. Dynan WS, Yoo S (1998) Interaction of Ku protein and DNAdependent protein kinase catalytic subunit with nucleic acids. Nucleic Acids Res 26:1551-9. https://doi.org/10.1093/nar/26.7. 1551

14. De Zio D, Bordi M, Cecconi F (2012) Oxidative DNA damage in neurons: implication of ku in neuronal homeostasis and survival. Int J Cell Biol 2012:752420. https://doi.org/10.1155/2012/752420

15. Jette N, Lees-Miller SP (2015) The DNA-dependent protein kinase: A multifunctional protein kinase with roles in DNA double strand break repair and mitosis. Prog Biophys Mol Biol 117:194-205. https://doi.org/10.1016/j.pbiomolbio.2014.12.003

16. Guo Z, Deshpande R, Paull TT (2010) ATM activation in the presence of oxidative stress. Cell Cycle 9:4805-4811. https://doi. org/10.4161/cc.9.24.14323

17. Zhan H, Suzuki T, Aizawa K, Miyagawa K, Nagai R (2010) Ataxia telangiectasia mutated (ATM)-mediated DNA damage response in oxidative stress-induced vascular endothelial cell senescence. J Biol Chem 285:29662-70. https://doi.org/10.1074/jbc.M110. 125138

18. Rotman G, Shiloh Y (1997) Ataxia-telangiectasia: is ATM a sensor of oxidative damage and stress? BioEssays 19:911-7. https:// doi.org/10.1002/bies.950191011

19. Li M, Lin YF, Palchik GA, Matsunaga S, Wang D, Chen BP (2014) The catalytic subunit of DNA-dependent protein kinase is required for cellular resistance to oxidative stress independent of DNA double-strand break repair. Free Radic Biol Med 76:278285. https://doi.org/10.1016/j.freeradbiomed.2014.08.019

20. Parlanti E, Locatelli G, Maga G, Dogliotti E (2007) Human base excision repair complex is physically associated to DNA replication and cell cycle regulatory proteins. Nucleic Acids Res 35:1569-1577. https://doi.org/10.1093/nar/gk11159

21. Levy N, Martz A, Bresson A, Spenlehauer C, de Murcia G, Menissier-de Murcia J (2006) XRCC1 is phosphorylated by DNAdependent protein kinase in response to DNA damage. Nucleic Acids Res 34:32-41. https://doi.org/10.1093/nar/gkj409

22. Peddi P, Loftin CW, Dickey JS, Hair JM, Burns KJ, Aziz K, Francisco DC, Panayiotidis MI, Sedelnikova OA, Bonner WM, Winters TA, Georgakilas AG (2010) DNA-PKcs deficiency leads to persistence of oxidatively induced clustered DNA lesions in human tumor cells. Free Radic Biol Med 48:1435-1443. https:// doi.org/10.1016/j.freeradbiomed.2010.02.033

23. Greene LA, Tischler AS (1976) Establishment of a noradrenergic clonal line of rat adrenal pheochromocytoma cells which respond to nerve growth factor. Proc Natl Acad Sci USA 73:2424-8. https://doi.org/10.1073/pnas.73.7.2424

24. Sheehy AM, Phung YT, Riemer RK, Black SM (1997) Growth factor induction of nitric oxide synthase in rat pheochromocytoma cells. Brain Res Mol Brain Res 52:71-77. https://doi.org/10.1016/ s0169-328x(97)00224-6

25. Bao D, Wang J, Pang X, Liu H (2017) Protective effect of quercetin against oxidative stress-induced cytotoxicity in rat pheochromocytoma (PC-12) cells. Molecules. https://doi.org/10.3390/ molecules22071122

26. Wu XJ, Zheng YJ, Cui YY, Zhu L, Lu Y, Chen HZ (2007) Propofol attenuates oxidative stress-induced PC12 cell injury via p38 MAP kinase dependent pathway. Acta Pharmacol Sin 28:1123-8. https://doi.org/10.1111/j.1745-7254.2007.00610.x

27. Mollinari C, Ricci-Vitiani L, Pieri M, Lucantoni C, Rinaldi AM, Racaniello M, De Maria R, Zona C, Pallini R, Merlo D, Garaci E (2009) Downregulation of thymosin beta4 in neural progenitor grafts promotes spinal cord regeneration. J Cell Sci 122:41954207. https://doi.org/10.1242/jcs.056895

28. Mollinari C, Racaniello M, Berry A, Pieri M, de Stefano MC, Cardinale A, Zona C, Cirulli F, Garaci E, Merlo D (2015) miR-34a regulates cell proliferation, morphology and function of newborn neurons resulting in improved behavioural outcomes. Cell Death Dis 6:e1622. https://doi.org/10.1038/cddis.2014.589

29. Nicoletti I, Migliorati G, Pagliacci MC, Grignani F, Riccardi C (1991) A rapid and simple method for measuring thymocyte apoptosis by propidium iodide staining and flow cytometry. J Immunol Methods 139:271-9. https://doi.org/10.1016/0022-1759(91) 90198-o

30. Simon HU, Haj-Yehia A, Levi-Schaffer F (2000) Role of reactive oxygen species (ROS) in apoptosis induction. Apoptosis 5:415-8. https://doi.org/10.1023/a:1009616228304

31. Redza-Dutordoir M, Averill-Bates DA (2016) Activation of apoptosis signalling pathways by reactive oxygen species. Biochim Biophys Acta 1863:2977-2992. https://doi.org/10.1016/j.bbamcr. 2016.09.012

32. Narciso L, Parlanti E, Racaniello M, Simonelli V, Cardinale A, Merlo D, Dogliotti E (2016) The Response to Oxidative DNA Damage in Neurons: Mechanisms and Disease. Neural Plast 2016:3619274. https://doi.org/10.1155/2016/3619274

33. Lu J, Li Y, Mollinari C, Garaci E, Merlo D, Pei G (2019) Amyloid-beta oligomers-induced mitochondrial DNA repair impairment contributes to altered human neural stem cell differentiation. Curr Alzheimer Res 16:934-949. https://doi.org/10.2174/15672 05016666191023104036

34. Cardinale A, Racaniello M, Saladini S, De Chiara G, Mollinari C, de Stefano MC, Pocchiari M, Garaci E, Merlo D (2012) Sublethal doses of beta-amyloid peptide abrogate DNA-dependent protein kinase activity. J Biol Chem 287:2618-2631. https://doi.org/10. 1074/jbc.M111.276550

35. Gottlieb TM, Jackson SP (1993) The DNA-dependent protein kinase: requirement for DNA ends and association with Ku antigen. Cell 72:131-142. https://doi.org/10.1016/0092-8674(93) 90057-w

36. Collis SJ, DeWeese TL, Jeggo PA, Parker AR (2005) The life and death of DNA-PK. Oncogene 24:949-961. https://doi.org/ 10.1038/sj.onc. 1208332

37. Orii KE, Lee Y, Kondo N, McKinnon PJ (2006) Selective utilization of nonhomologous end-joining and homologous recombination DNA repair pathways during nervous system development. Proc Natl Acad Sci U S A 103:10017-10022. https://doi.org/10. 1073/pnas.0602436103

38. McKinnon PJ (2009) DNA repair deficiency and neurological disease. Nat Rev Neurosci 10:100-112. https://doi.org/10.1038/ nrn2559

39. Rukenstein A, Rydel RE, Greene LA (1991) Multiple agents rescue PC12 cells from serum-free cell death by translation- and transcription-independent mechanisms. J Neurosci 11:2552-2563

40. Greene LA (1978) Nerve growth factor prevents the death and stimulates the neuronal differentiation of clonal PC12 pheochromocytoma cells in serum-free medium. J Cell Biol 78:747-755. https://doi.org/10.1083/jcb.78.3.747

41. Xiao X, Liu J, Hu J, Zhu X, Yang H, Wang C, Zhang Y (2008) Protective effects of protopine on hydrogen peroxide-induced oxidative injury of $\mathrm{PC} 12$ cells via $\mathrm{Ca}(2+)$ antagonism and antioxidant mechanisms. Eur J Pharmacol 591:21-27. https://doi.org/ 10.1016/j.ejphar.2008.06.045

42. Ishima T, Nishimura T, Iyo M, Hashimoto K (2008) Potentiation of nerve growth factor-induced neurite outgrowth in PC12 cells by donepezil: role of sigma-1 receptors and IP3 receptors. Prog Neuropsychopharmacol Biol Psychiatry 32:1656-9. https://doi. org/10.1016/j.pnpbp.2008.06.011 
43. Manning BD, Cantley LC (2007) AKT/PKB signaling: navigating downstream. Cell 129:1261-1274. https://doi.org/10.1016/j.cell. 2007.06.009

44. Hemmings BA, Restuccia DF (2012) PI3K-PKB/Akt pathway. Cold Spring Harb Perspect Biol 4:a011189. https://doi.org/10. 1101/cshperspect.a011189

45. Feng J, Park J, Cron P, Hess D, Hemmings BA (2004) Identification of a PKB/Akt hydrophobic motif Ser-473 kinase as DNAdependent protein kinase. J Biol Chem 279:41189-96. https://doi. org/10.1074/jbc.M406731200

46. Bozulic L, Hemmings BA (2009) PIKKing on PKB: regulation of PKB activity by phosphorylation. Curr Opin Cell Biol 21:256261. https://doi.org/10.1016/j.ceb.2009.02.002

47. Miller DK (1997) The role of the Caspase family of cysteine proteases in apoptosis. Semin Immunol 9:35-49. https://doi.org/10. 1006/smim.1996.0058

48. Li J, Yuan J (2008) Caspases in apoptosis and beyond. Oncogene 27:6194-6206. https://doi.org/10.1038/onc.2008.297

49. Gilliams-Francis KL, Quaye AA, Naegele JR (2003) PARP cleavage, DNA fragmentation, and pyknosis during excitotoxininduced neuronal death. Exp Neurol 184:359-372. https://doi.org/ 10.1016/j.expneurol.2003.07.003

50. Hoeijmakers JH (2001) Genome maintenance mechanisms for preventing cancer. Nature 411:366-374. https://doi.org/10.1038/ 35077232

51. d'Adda di Fagagna F (2008) Living on a break: cellular senescence as a DNA-damage response. Nat Rev Cancer 8:512-522. https:// doi.org/10.1038/nrc2440

52. Lindahl T (1993) Instability and decay of the primary structure of DNA. Nature 362:709-715. https://doi.org/10.1038/362709a0

53. Nouspikel T, Hanawalt PC (2000) Terminally differentiated human neurons repair transcribed genes but display attenuated global DNA repair and modulation of repair gene expression. Mol Cell Biol 20:1562-1570. https://doi.org/10.1128/mcb.20.5.15621570.2000

54. Nouspikel T (2007) DNA repair in differentiated cells: some new answers to old questions. Neuroscience 145:1213-1221. https:// doi.org/10.1016/j.neuroscience.2006.07.006

55. Davis AJ, Chen BP, Chen DJ (2014) DNA-PK: a dynamic enzyme in a versatile DSB repair pathway. DNA Repair (Amst) 17:21-29. https://doi.org/10.1016/j.dnarep.2014.02.020

56. Li X, Heyer WD (2008) Homologous recombination in DNA repair and DNA damage tolerance. Cell Res 18:99-113. https:// doi.org/10.1038/cr.2008.1

57. Anderson CW, Carter TH (1996) The DNA-activated protein kinase-DNA-PK. Curr Top Microbiol Immunol 217:91-111. https://doi.org/10.1007/978-3-642-50140-1_7
58. Huston E, Lynch MJ, Mohamed A, Collins DM, Hill EV, MacLeod R, Krause E, Baillie GS, Houslay MD (2008) EPAC and PKA allow cAMP dual control over DNA-PK nuclear translocation. Proc Natl Acad Sci USA 105:12791-6. https://doi.org/ 10.1073/pnas.0805167105

59. Abner CW, McKinnon PJ (2004) The DNA double-strand break response in the nervous system. DNA Repair (Amst) 3:1141-7. https://doi.org/10.1016/j.dnarep.2004.03.009

60. Stronach EA, Chen M, Maginn EN, Agarwal R, Mills GB, Wasan $\mathrm{H}$, Gabra H (2011) DNA-PK mediates AKT activation and apoptosis inhibition in clinically acquired platinum resistance. Neoplasia 13:1069-1080. https://doi.org/10.1593/neo.111032

61. Park J, Feng J, Li Y, Hammarsten O, Brazil DP, Hemmings BA (2009) DNA-dependent protein kinase-mediated phosphorylation of protein kinase $B$ requires a specific recognition sequence in the C-terminal hydrophobic motif. J Biol Chem 284:6169-6174. https://doi.org/10.1074/jbc.C800210200

62. Surucu B, Bozulic L, Hynx D, Parcellier A, Hemmings BA (2008) In vivo analysis of protein kinase $B$ (PKB)/Akt regulation in DNA-PKcs-null mice reveals a role for PKB/Akt in DNA damage response and tumorigenesis. J Biol Chem 283:30025-30033. https://doi.org/10.1074/jbc.M803053200

63. Hill MM, Hemmings BA (2002) Inhibition of protein kinase B/ Akt. implications for cancer therapy. Pharmacol Ther 93:243-251. https://doi.org/10.1016/s0163-7258(02)00193-6

64. Dong J, Ren Y, Zhang T, Wang Z, Ling CC, Li GC, He F, Wang C, Wen B (2018) Inactivation of DNA-PK by knockdown DNAPKcs or NU7441 impairs non-homologous end-joining of radiation-induced double strand break repair. Oncol Rep 39:912-920. https://doi.org/10.3892/or.2018.6217

65. van Bussel MTJ, Awada A, de Jonge MJA, Mau-Sorensen M, Nielsen D, Schoffski P, Verheul HMW, Sarholz B, Berghoff K, El Bawab S, Kuipers M, Damstrup L, Diaz-Padilla I, Schellens JHM (2021) A first-in-man phase 1 study of the DNA-dependent protein kinase inhibitor peposertib (formerly M3814) in patients with advanced solid tumours. Br J Cancer 124:728-735. https:// doi.org/10.1038/s41416-020-01151-6

Publisher's Note Springer Nature remains neutral with regard to jurisdictional claims in published maps and institutional affiliations. 